\title{
QUATERNARY ALLUVIAL SINKHOLES: RECORD OF ENVIRONMENTAL CONDITIONS OF KARST DEVELOPMENT, EXAMPLES FROM THE EBRO BASIN, SPAIN
}

\author{
María Asunción Soriano*, Aránzazu luzón, Alfonso Yuste, Andrés Pocoví, Antonio Pérez, \\ José Luis Simón, AND HÉctor GiL \\ Dpto. Ciencias de la Tierra, Universidad de Zaragoza, cl Pedro Cerbuna 12, Zaragoza, 50009, Spain
}

\begin{abstract}
The central Ebro Basin is an exceptional region for studying karstification through time and under different environmental conditions, as sinkholes have been developing since the Early Pleistocene. Knowledge of active sinkholes is complemented with research on paleosinkholes and contemporary deposits. Sedimentological, mineralogical, geomorphological and structural approaches permit interpretation of the natural environmental conditions that favored karst in the past and the main genetic mechanisms involved. The sedimentary features of Pleistocene terraces indicate that they were deposited by a gravel braided fluvial system characterized by higher water and sediment availability than today, probably related to meltwater flows coming from glaciated source areas, mainly in the Pyrenees. Genesis of paleosinkholes was mainly linked to this high water supply. Some of them acted as small lakes where fine sediments are exceptionally well conserved to give clues about environmental conditions. The neoformation of palygorskite and sepiolite suggests arid to semiarid climatic conditions, in agreement with the idea of cold glacial episodes. During Pleistocene times, development of sinkholes was influenced by tectonics. Currently, the genesis and evolution of numerous sinkholes are also influenced by water supplies from human activities such as irrigation or urbanization, sharply changing the nearly steady state exhibited in the past.
\end{abstract}

\section{INTRODUCTION}

Karstification requires soluble rock, favorable climatic factors, and a hydraulic gradient that facilitates water mobility (White, 1988). Karst environments have different characteristics than others, in particular, the role of water circulation. Environmental changes cause variations in karst development, owing to the great sensitivity and vulnerability of karst areas to modifications in water availability and gradient (van Beynen and Townsend, 2005). This can even cause ending of karst development in some areas, giving rise to paleokarst (Shunk et al., 2006; Chow and Wendte, 2011). The environmental modifications can be of either natural or human origin, with the latter being more rapid (Ford and Williams, 2007) and also shown by several significant historical examples (Jia and Yuan, 2004; Beach et al., 2008; Closson and Abou Karaki, 2009 and references therein).

Evaporite karst in the central Ebro Basin has been broadly studied for decades since high solubility of evaporites and the heavy human occupation of the karst evaporite zone (around 700,000 inhabitants) increase the risk. The morphology of sinkholes and their genetic mechanisms, spatial distribution, and associated risks are well known (Soriano, 1992; Soriano and Simón, 2002 and references therein; Lamelas et al., 2008; Galve et al., 2009 and references therein).
Sinkholes in this area are not only recent, but also paleosinkholes affecting Quaternary sediments can be observed in artificial outcrops in the whole area (Luzón et al., 2008; Gutiérrez et al., 2008; Benito et al., 2010). This indicates that karstification occurred before human influences and makes the Ebro Basin an exceptional place to study sinkholes through time and under different environmental conditions.

As a consequence, the study of present-day sinkholes should be integrated with research about paleosinkholes and their related deposits to better understand the natural environmental conditions that favored karst in the past. Moreover, the study of paleosinkholes permits a wider time window for the study of sinkholes, a direct access to their inner structure and, consequently, to the main genetic mechanisms involved. It allows us to characterize the main stages in a sinkhole's evolution, as well as to constrain its period of development. The main purpose of this work is the study of present-day and ancient sinkholes and the environment, both natural and anthropogenic, in which they developed. These include natural settings under a cold Pleistocene climate and human-influenced conditions under present-day semiarid climate. To achieve these objectives, a multifaceted

* Corresponding author: asuncion@unizar.es

Journal of Cave and Karst Studies, August 2012•173 


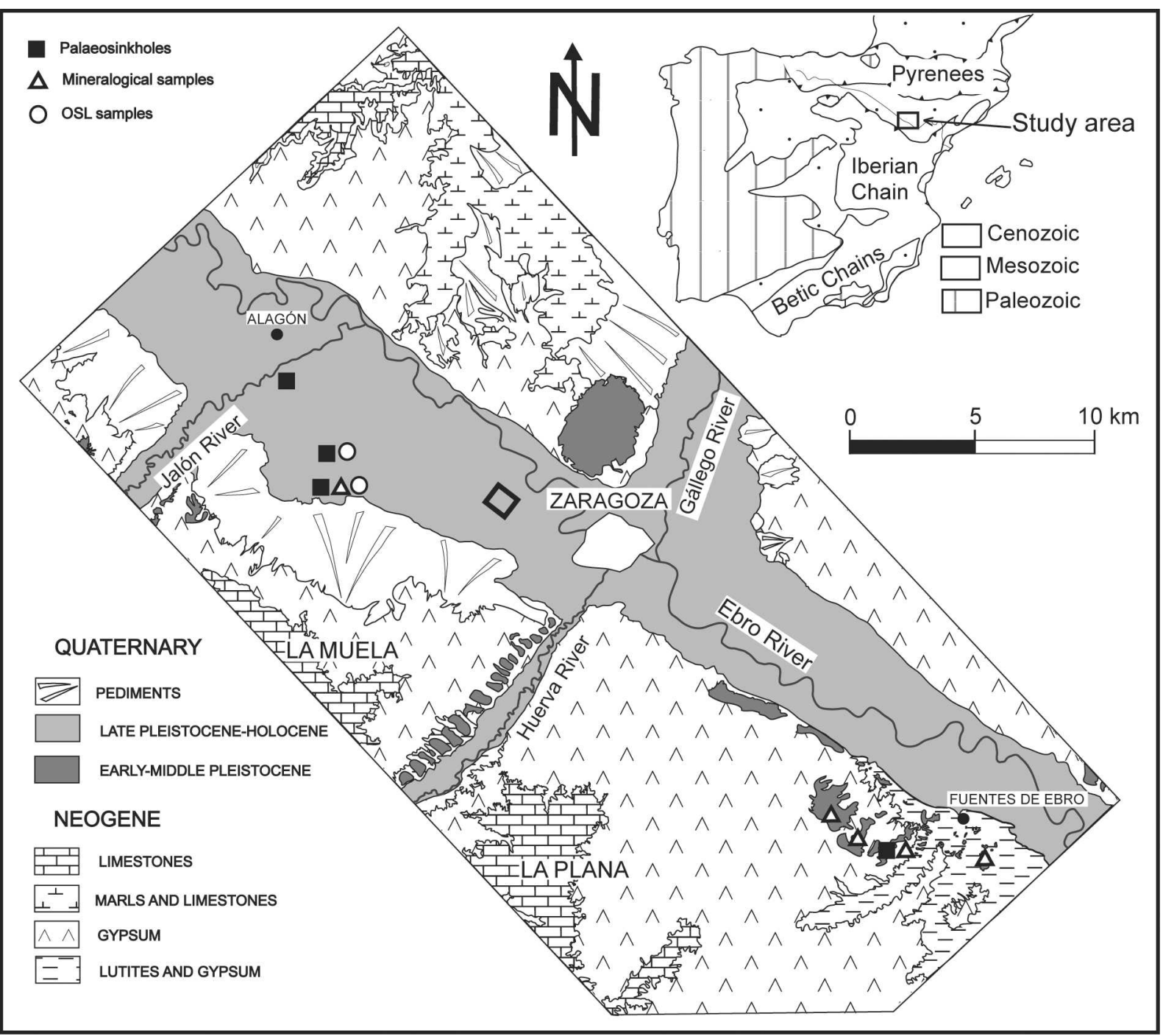

Figure 1. Location of the studied area in northeastern Spain and geological map of the central Ebro Basin. An open square indicates location of Figure 3.

approach has been carried out, including sedimentological, mineralogical, geomorphological, and structural studies.

\section{Geological and Geographical Setting}

The study area (Fig. 1) is located in the central part of the Ebro Basin in northeastern Spain, which is the foreland basin of the Pyrenean alpine orogen. This basin is bounded by the Iberian Range to the south and the Catalonian Coastal Range to the east, and is crossed by the Ebro River that flows towards the Mediterranean Sea to the east. The basin was endorheic from the Late Eocene to the MiddleLate Miocene (García-Castellanos et al., 2003) and alluvial fans sourced in the surrounding mountains interfered with central saline or carbonate lakes (Muñoz et al., 2002; Pardo et al., 2004). Due to this paleogeographical distribution, the stratigraphic succession in the central part of the basin is characterized mainly by thick, nearly horizontal carbonate or evaporite rocks. In the study area, the outcropping Miocene units are mainly composed of evaporite rocks with interbedded marl, the Zaragoza Formation. A regional disconformity separates the Miocene rocks from the Quaternary deposits. The latter have been traditionally considered to be fluvial terraces belonging to the Ebro River and its main tributaries, and pediments. Soriano (1990) recognized eight stepped terrace levels in the area, as well as six pediment levels. Thickness of the terrace levels is variable, the three youngest being the best-preserved. Fluvial deposits are mainly composed of polygenic gravels with interbedded sands and very scarce lutites. Thickness of the pediments, consisting of sands, lutites, and angular to sub-angular gravels, is also variable.

The Miocene beds usually lie nearly horizontal, although gentle folds and faults have been recognized. The Quaternary deposits have been affected by tectonic, gravitational, diapiric, and dissolution processes (Simón and Soriano, 
1986; Benito and Casas, 1987; Arlegui and Simón, 2000). As previously mentioned, karstification is currently the most active geological process in the central Ebro Basin caused by dissolution of Miocene evaporite rocks and their subsequent collapse, subsidence, and suffosion of the Quaternary detrital cover.

Climate in this area is semiarid, with mean annual precipitation between 200 and $300 \mathrm{~mm}$ irregularly distributed over the year and a mean annual temperature of about $15{ }^{\circ} \mathrm{C}$. Precipitation reaches some 400 to $500 \mathrm{~mm}$ during occasional humid years and, exceptionally, almost $700 \mathrm{~mm}$, as in 1990. At present, the Ebro River shows a meandering pattern and a wide flood plain, densely occupied by human settlements.

\section{Methods}

In this work, different traditional geologic methods have been utilized to analyze the characteristics of sinkholes, especially those developed during the Pleistocene.

In the study of recent sinkholes, analysis and comparison of aerial photographs from various years $(1927,1946$, 1957, 1970, 1982, 1986, 1988, 1993, 1999, and 2006) with scales ranging from $1: 43,000$ to $1: 5,000$ allow us to identify depressions larger than $10 \mathrm{~m}$ in diameter and to determine spatial variations through time. Fieldwork facilitates the identification of smaller depressions, the corroboration of the presence of the larger ones, and the study of damage in urban areas at a detailed scale (Simón et al., 1998).

To study paleosinkholes and to characterize the environmental conditions under which they developed, a sedimentological analysis was carried out in the Pleistocene succession through the application of facies analysis (Miall, 1978). The studied sections mainly occur on Middle-Late Pleistocene and Early Pleistocene terraces, as well as pediments. Multiple survey lines were analyzed along quarry faces and artificial slopes of roads and railways, with a total length of about $30 \mathrm{~km}$. Typical sections are several tens of meters long and 10 to 20 meters high, providing a good view and sufficient samples. Four paleosinkholes were selected for detailed study, based on evidence of synsedimentary deformation, the size and quality of the sections, and the presence of a non-deformed sedimentary cover.

The sedimentological and paleoenvironmental analysis was completed with the mineralogical study of five sediment filled paleosinkholes (Fig. 1). A total of thirty-three marl and sand samples (thirteen from Early Pleistocene and twenty from Middle-Late Pleistocene deposits) were analyzed to determine their mineralogical composition and texture. Mineralogical compositions of whole samples, as well as air-dried and ethylene glycol treated and dimethyl sulfoxide-treated oriented samples of the finer fractions ( 2 to $20 \mu \mathrm{m}$ and $<2 \mu \mathrm{m}$ ), were determined by X-ray diffraction. In addition, the absolute intensity ratio of the smectite and illite 001 reflections $\left(I_{S m} / I_{I I}\right)$ was calculated

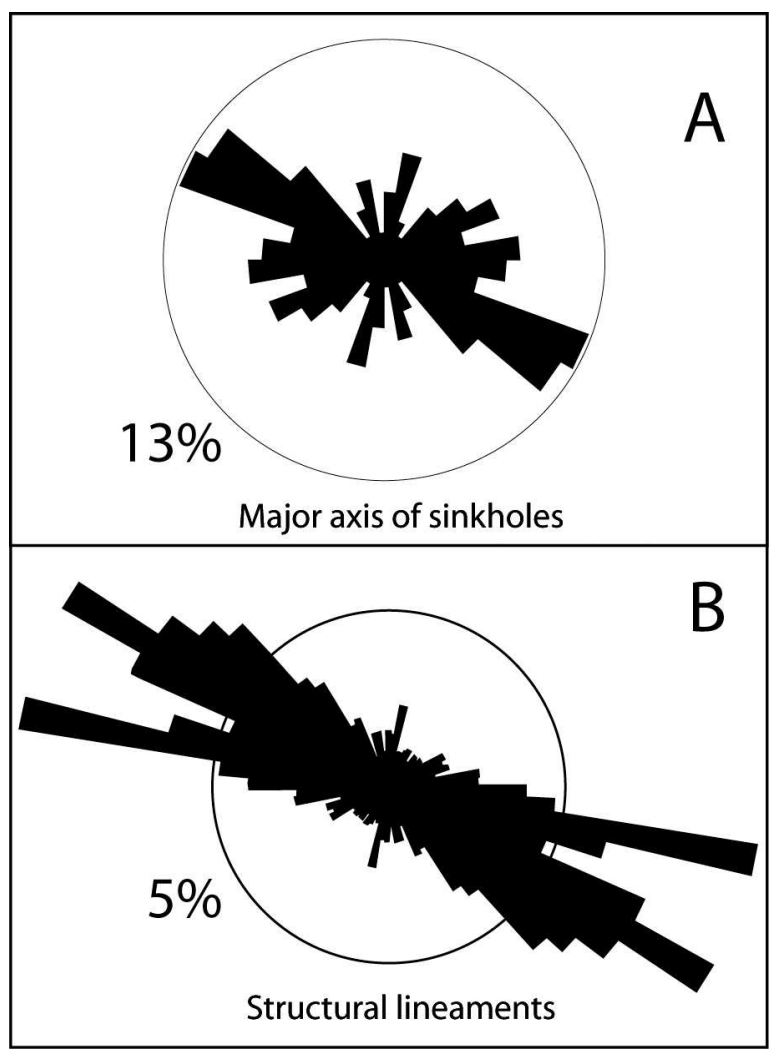

Figure 2. Rose diagrams. A, Major axis orientation of recent sinkholes. B, Lineaments of the central Ebro Basin after Arlegui and Soriano (1998).

from the glycoated oriented samples. Microtextural and morphological observations were performed by scanning electron microscopy observing gold-coated fragments of selected samples using secondary electron imaging. Chemical analyses and morphological studies of phyllosilicate particles from the $<2 \mu \mathrm{m}$ fraction of selected samples were carried out by transmission electron microscope equipped with an EDX analytical system.

Four samples were collected from two quarries (Fig. 1) for dating by the optically stimulated luminescence (OSL) method, following standard procedure to avoid light exposure. The preparation and pre-treatment of the samples for OSL dating was carried out in the Laboratorio de Datación y Radioquímica of the Universidad Autónoma de Madrid, using the additive dose method for fine grain size. OSL measurements were performed using a Risø TL/OSL-DA-10 device.

To determine the mechanisms of sinkhole development, deformational structures were studied by means of standard field surveys and analyses including recording detailed crosssections on quarry faces where such structures are well exposed, exhaustive compilation of data on faults, joints, and folds in both Pleistocene deposits and Tertiary rocks, and retrodeformational analysis directed toward kinematical reconstruction of structures and discrimination of deformational mechanisms. 

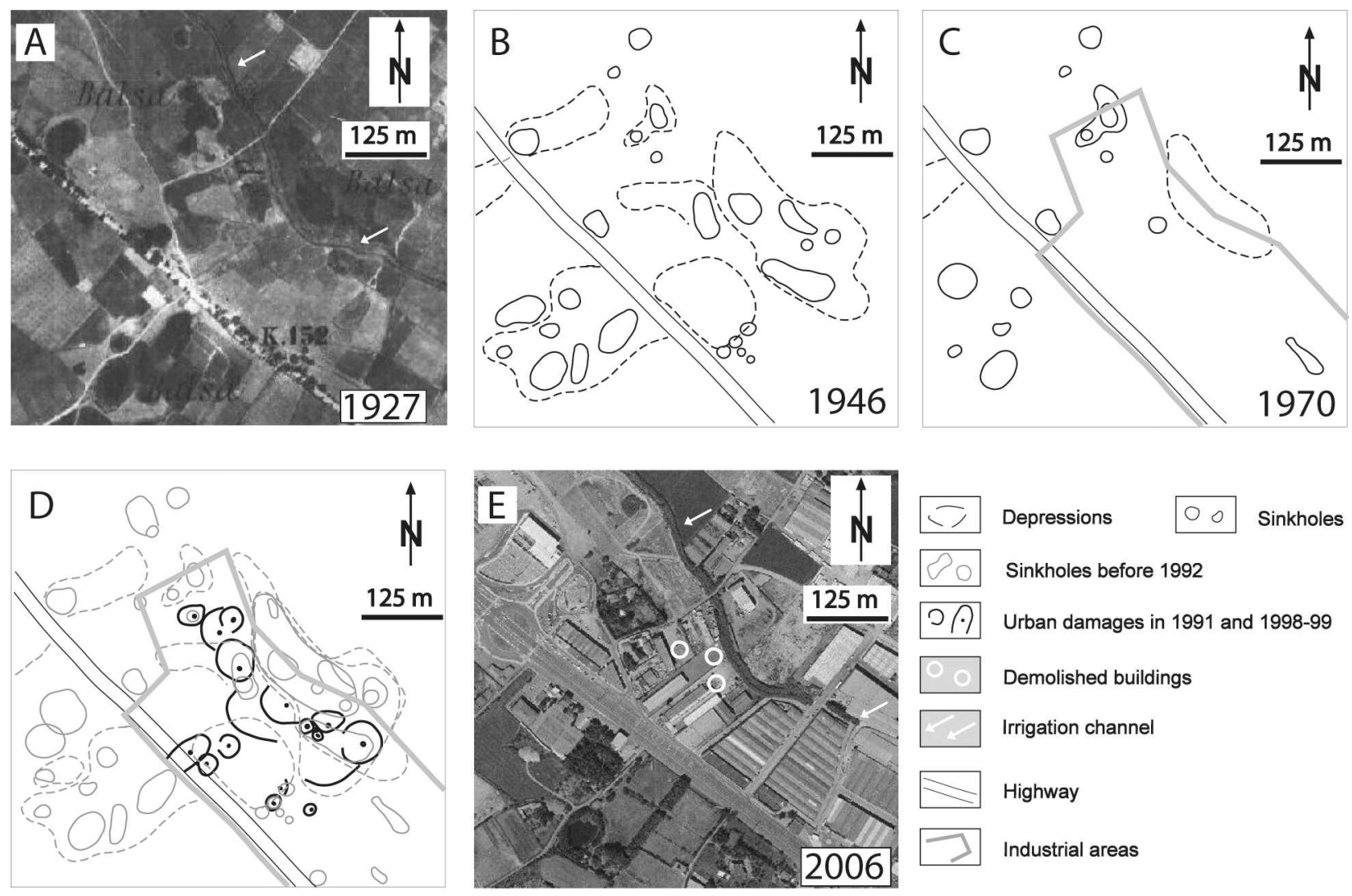

Figure 3. Aerial photographs and geomorphological maps of sinkholes near Zaragoza (see location in Fig. 1). A, aerial photograph of 1927. B and C, geomorphological maps based on aerial photographs of 1946 and 1970, respectively. D, damages in urban zones (in black) allow to map present sinkholes and to monitor their activity; comparison with sinkholes mapped from aerial photographs before 1992 (in gray) shows a spatial relation between them. E, aerial photograph of 2006; in this zone three buildings had to be demolished due to severe damage caused by sinkhole activity.

\section{RESUlts AND Discussion}

\section{Modern SinkHoles}

More than three hundred sinkholes have been recognized (see Figure 1 in Soriano and Simón, 2002) between Alagón and Zaragoza (Fig. 1). Most of them are circular or subcircular, attaining up to $1200 \mathrm{~m}$ in diameter and 20 to $25 \mathrm{~m}$ in depth. Major axes of sinkholes show an average trend N $130^{\circ}$ E (Soriano, 1992; Gutiérrez-Santolalla et al., 2005b) that is parallel to the central Ebro Basin main lineament set determined by Arlegui and Soriano (1998) (Fig. 2). This points out the structural control that favored the circulation of water and the subsequent dissolution of evaporites.

Other natural factors, mostly related to water availability, influence the development of sinkholes in the region. Generation and subsidence of sinkholes clearly increase after heavy storms and in years with higher precipitation than usual (Soriano and Simón, 2002; Gutiérrez-Santolalla et al., 2005a). Nevertheless, the control that land use exerts on karst evolution is noteworthy, as discusssed below.

Analysis of aerial photographs indicates that prior to 1970 most of the land surface was dedicated to agriculture.
Sinkholes were numerous (Fig. 3A and B) and coexisted with farming activities. An almost steady state could be inferred for that time; comparison of sinkholes identified in aerial photographs of different years shows that their total number remained approximately constant (Simón et al., 2008). Strong differences between the number of sinkholes in irrigated (mean density 5.8 sinkholes per $\mathrm{km}^{2}$ ) and nonirrigated fields (mean density $=1.47$ ) were observed, as well as a high number of sinkholes, about half of them, (Soriano, 1992 and references therein) developed in connection with irrigation channels (Fig. 3). Human influence continues at present, since irrigation techniques in this zone mostly follow very old practices consisting in field flooding. In fact, groundwater recharge by natural precipitation is estimated in $9 \times 10^{6} \mathrm{~m}^{3} / \mathrm{y}$, while irrigation supplies $171 \times 10^{6} \mathrm{~m}^{3} / \mathrm{y}$ (Confederación Hidrográfica del Ebro, 2010). The large amount of irrigation contributes to increased variation in water level, hydraulic gradient, dissolution of evaporites in the subsoil, and mobilization of detrital material through the voids, with subsequent generation of sinkholes (Currin and Barfus, 1989; Simón et al. 2008; Mancini et al., 2009).

By 1970, although large areas of land remained dedicated to agriculture, important changes in land use had occurred 

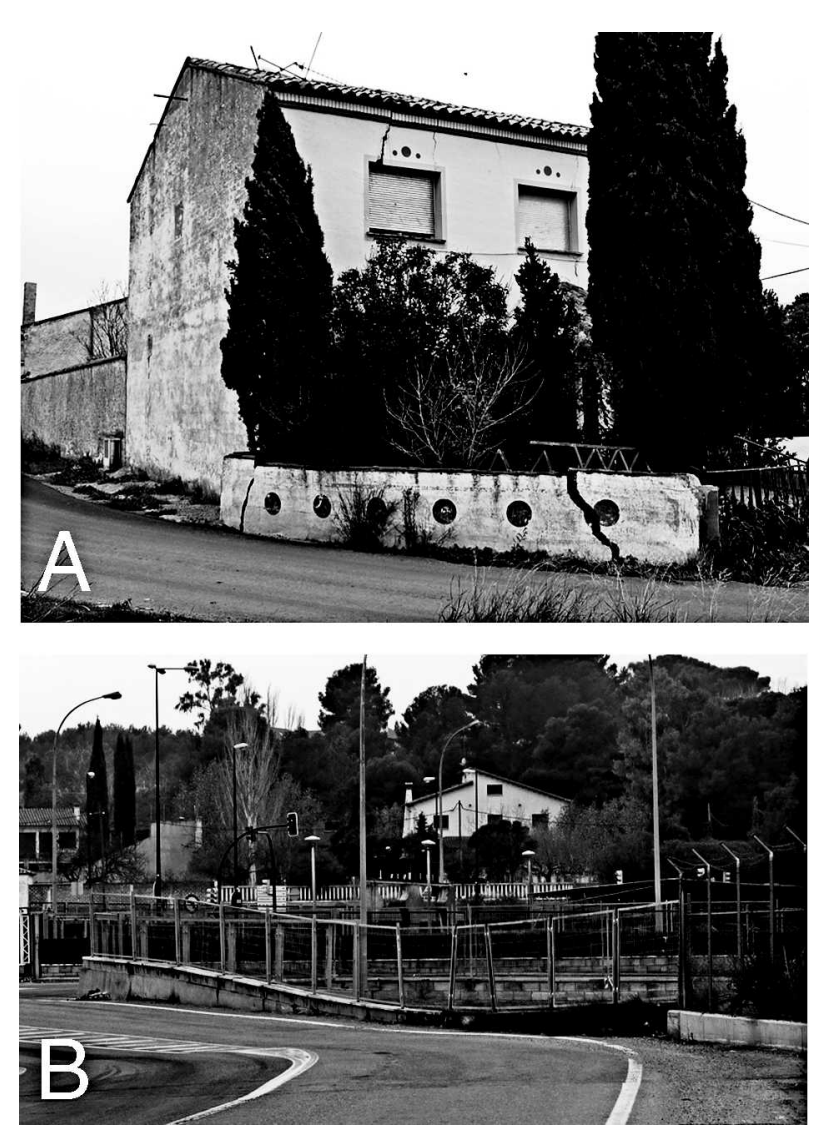

Figure 4. Damage in urban areas northwest of the city of Zaragoza resulting from karst subsidence. $A$, fractures in walls. $B$, strong deformation of a fence.

in the areas surrounding both the urban settlements and the main roads. Some agricultural lands had become urban and industrial areas. Many sinkholes were filled (Fig. 3C), mainly with aggregates, concrete, building rubble, and other waste. Consequently, marked spatial changes took place, with a clear decrease in the number of visible sinkholes (Simón et al., 2008).

In spite of sinkhole filling, dissolution and suffosion processes are still active. Subsidence reappears over a period of time as the source of water from irrigation continues (Soriano and Simón, 2002 and references therein). The consequences in urbanized areas are damages to buildings and infrastructures (Fig. 3D and E and Fig. 4). Study of cracks in walls, floors, and roofs, the subsidence of pavements, breaks in water supply systems, and the collapse of roads or railways allows us to identify subsidence centers (Fig. 3D) and establish the scale of damages (Cooper and Calow, 1998; Soriano and Simón, 2002; Pueyo-Anchuela et al., 2010). Frequently, migration of subsidence centers occurs (Soriano and Simón, 2002 and references therein; Pueyo-Anchuela et al., 2010), probably due to changes in the groundwater flow and gradient caused by artificial fill. Observing the sinkholes in the urban areas allows us to study spacial and temporal variations in their development, as well

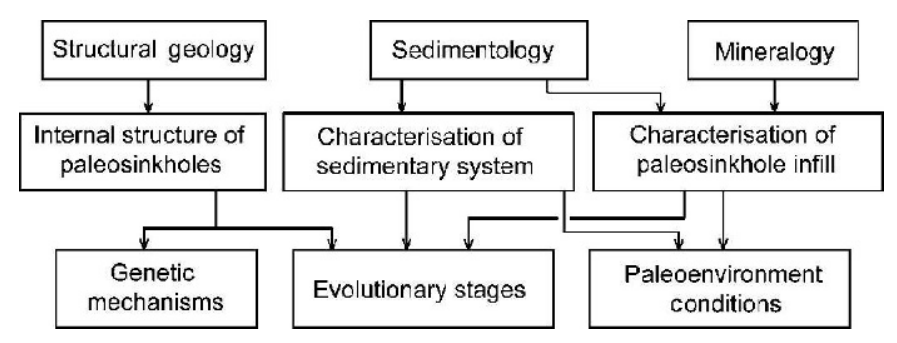

Figure 5. Schematic diagram showing the multifaceted approach to the study of paleosinkholes.

as the overall rate of subsidence, which in the central Ebro Basin ranges from 1.7 to $11 \mathrm{~cm} / \mathrm{yr}$ (Simón et al., 2008 and references therein). In summary, human action has modified the almost steady sinkhole development existing before 1970 .

\section{Paleosinkholes}

The previous section discusses the human influence on the generation of present-day sinkholes. However, the presence of Pleistocene paleosinkholes reveals that karstification occurred by natural causes in past epochs. Sedimentological, mineralogical, and structural studies help to reach insights into these phenomena (Fig. 5). The studied sections mainly correspond to low and high terrace levels. Dating by OSL indicates that the low terraces are Late Pleistocene, while the higher terraces are considered, by their stratigraphical position and magnetostratigraphical data, to be Early Pleistocene in age (Benito et al., 1998; Marqués et al., 1998; Colomer et al., 2006). Paleosinkholes are exposed, mainly on quarry faces and road slopes. The observed sedimentary infilling usually ranges from 2 to $25 \mathrm{~m}$ in width and from 2 to $15 \mathrm{~m}$ in height, although several sinkholes are only partially exposed and might continue at greater depths into the subsoil.

\section{Sedimentological Data}

Thick successions of gravels with interbedded sands and lutites are predominate in the Pleistocene terrace deposits. Clast-supported, well-sorted, rounded to subrounded gravels are the most common lithofacies, whereas lutites are only locally present. Gravels usually show imbrication and form thick tabular or subordinately channeled bodies with horizontal stratification and cross -stratification. Sands show different types of sedimentary structures (e.g., horizontal and cross-lamination). These deposits represent tractive processes and testify to the development of longitudinal bars, transverse bars, and channels in a gravel braided setting (Luzón et al., 2008). This scenario (Fig. 6A) strongly contrasts with the current meandering flow of the Ebro River and suggests greater water availability during the Pleistocene in a clearly different climate setting than present. Intercalated in these deposits, ancient sinkhole fillings are found in some zones (Figs. 7 and 8). They consist of lutites laterally passing to 

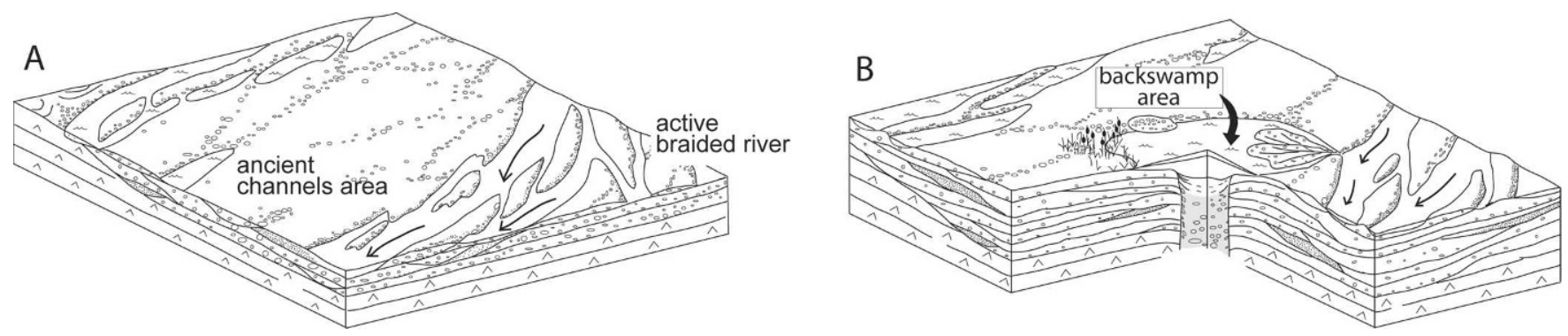

Figure 6. A, schematic diagram showing the sedimentary environment during the Pleistocene in the area and its relationship to the evaporite substratum. B, paleosinkholes often developed close to active channels and backswamp areas generated.

marginal gravel lobes, all making a U-shaped or basinform deposit (Fig. 7). In many cases, gravels form a progressive unconformity that indicates synsedimentary deformation (Fig. 8A). Less often, the U-shaped filling consists of well-sorted sands with trough cross-stratification and lamination. In some cases, several laterally connected U-shaped lutite bodies have been preserved (Fig. 8B). Among of the most interesting facies associated with paleosinkholes are disorganized gravels and gravels with vertical A-axis.

Taking into account the climate during the Pleistocene (García Ruiz and Martí Bono, 1994), the water availability was related to the existence of glaciers in the surrounding source areas, mainly the Pyrenees. The high and very variable water discharges due to ice melting in highlands create ideal conditions for braided-plain development (Boothroyd and Ashley, 1975; Miall, 1978; Rust, 1978; Maizels, 1997; Zielinski and Van Loon, 2003). Moreover, this provided the necessary water for karst development. Therefore, the genesis of sinkholes in the area was due to different conditions than those working at present, primarily those high natural water discharges.

Considering that fine deposits are usually eroded in gravel braided fluvial settings, as demonstrated by the very
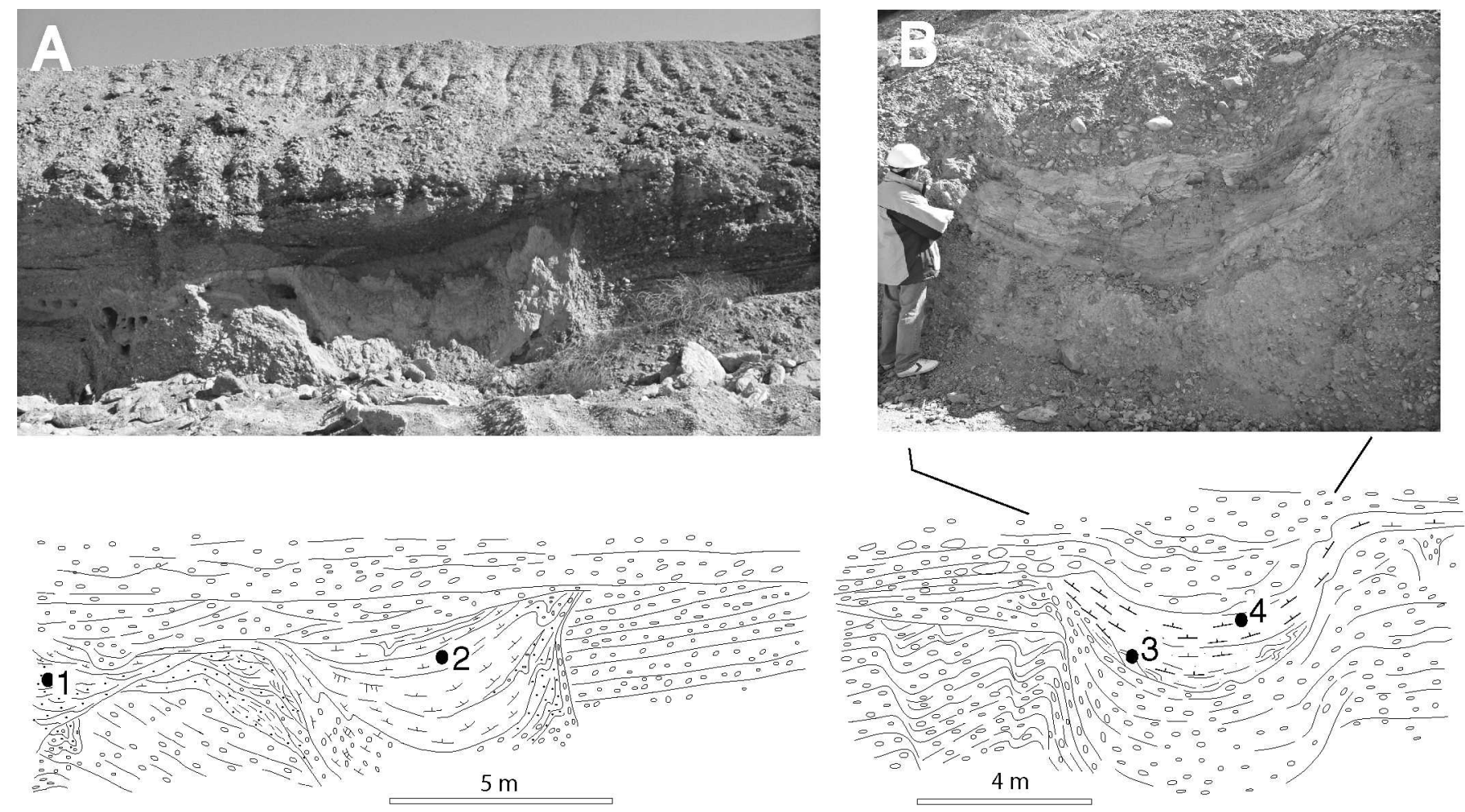

Figure 7. Photographs and cross-sections of two paleosinkholes filled with lutites and marginal deformed gravels. They are Ushaped deposits intercalated in tabular gravel beds where fine sediments were exceptionally well preserved in the fluvial context. A, the uppermost gravel levels are non-deformed and date the end of karstification. $\mathbf{B}$, the uppermost gravels are still deformed. Samples taken for dating by optically stimulated luminescence are indicated. 1: 57, $880 \pm 4,411 ; 2: 49,876 \pm 5,434 ; 3: 112,293$ \pm 10,059; 4: 111,662 \pm 9,745 yr BP.

178 Journal of Cave and Karst Studies, August 2012 

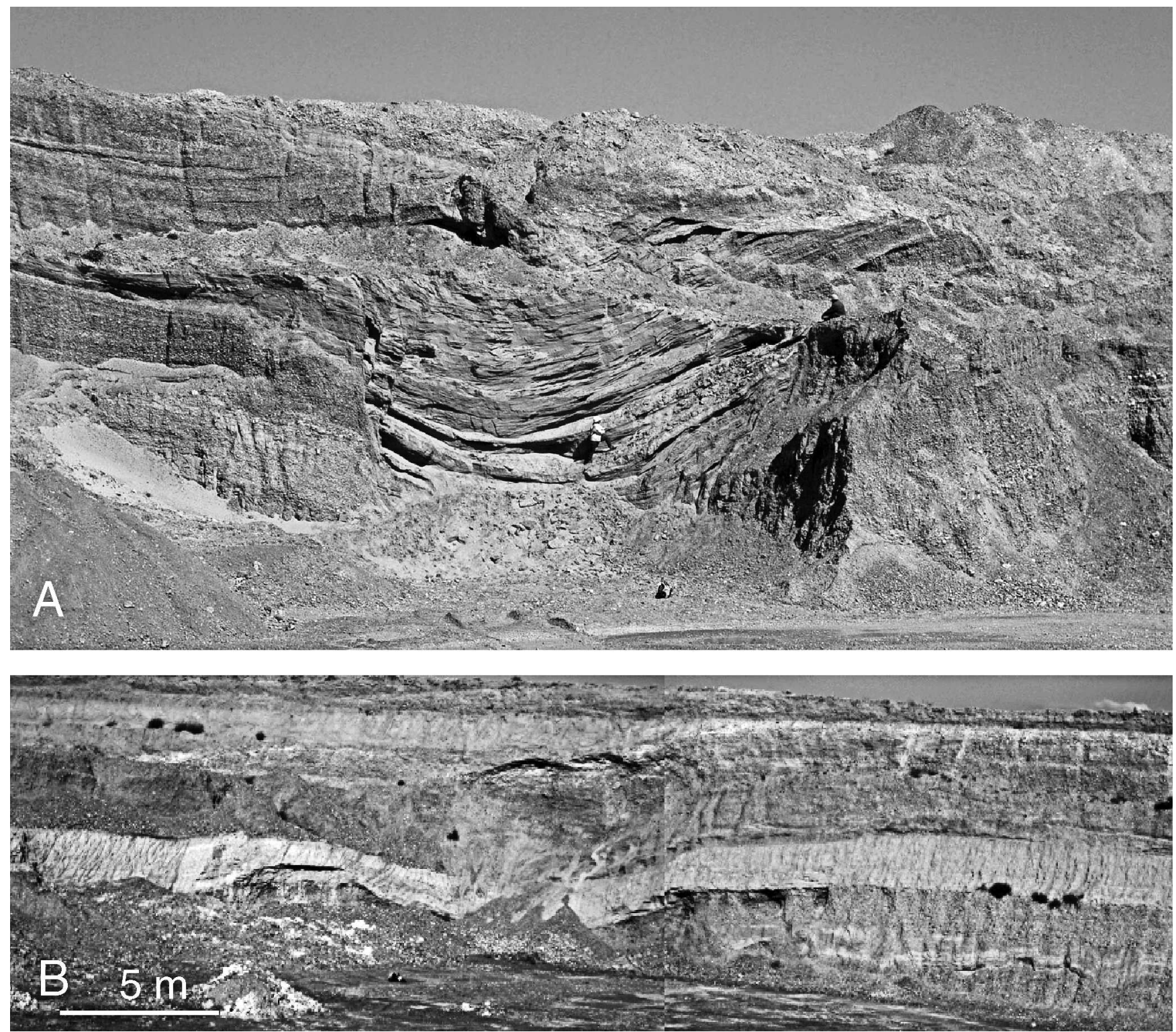

Figure 8. A, Early Pleistocene paleosinkhole with U-shaped sandy deposit; gravels in the right border show a progressive unconformity evincing synsedimentary deformation. B, a mainly tabular lutite bed with local thickenings interpreted as laterally connected small paleosinkholes.

rare presence of mudstones from flood-plain zones in the area, the negative relief of paleosinkholes made them excellent sites where fine sediments could be exceptionally preserved. This permitted us to analyze paleoenvironmental information that otherwise would have been lost.

When sinkholes developed in areas far from active flows but with high phreatic levels, they acted as small lakes in which lutites with rare marginal gravel lobes were deposited (Fig. 6B). During subsequent erosive episodes, the fine deposits could be preserved (Fig. 7). Wider lutite bodies such as those in Figure 8B are interpreted as floodplain deposits preserved in extensive subsiding areas with different local subsidence rates, a feature that we have also recognized in present-day sinkhole fields (Figs. 3A and B).
Moreover, when the phreatic level was almost coincident with the sedimentary surface, aeolian sands (Fig. 8A) were preserved within the sinkholes (Luzón et al., 2011). When sinkholes developed in active fluvial areas, disorganized gravels were deposited. Disorganized gravels and gravels with vertical A-axis clasts can also be generated by dissolution of the substratum, gravitational processes affecting previously deposited gravels, and dragging of the latter into the depressions.

Paleosinkholes also allow an approach to the duration of sinkholes development. OSL dating of two paleosinkholes (Fig. 7) indicates that they were filling for thousands of years. Assuming that deformation was synsedimentary, gives a rate of subsidence that ranges from 0.04 to $1 \mathrm{~mm} / \mathrm{yr}$. 


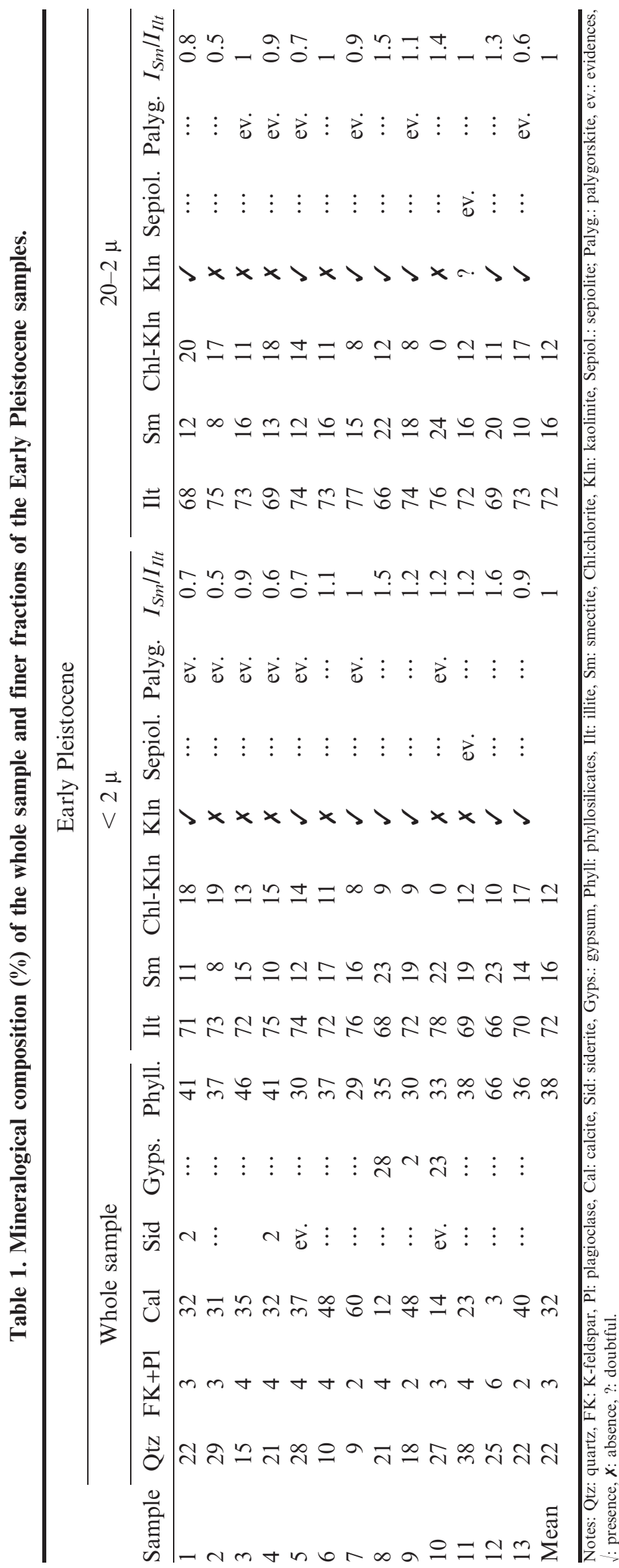

\section{Mineralogical Data}

When water flooded paleosinkholes, accumulation of lutites was frequent (Fig. 7). In these deposits, a detailed mineralogical study has been achieved.

$\mathrm{X}$-ray diffraction analysis (Tables 1 and 2) showed that the samples consist of phyllosilicates, calcite, and quartz, with accessory plagioclase and $\mathrm{K}$-feldspar and occasionally siderite and gypsum. In the finer fractions, illite is the main phyllosilicate, accompanied by chlorite+kaolinite and smectite. Evidences of palygorskite and, to a lesser extent, sepiolite have been observed, although they could not be quantified. Some differences in clay mineralogy can be seen if age of the paleosinkholes is taken into account. Early Pleistocene samples (Table 1) show on average higher smectite content than Middle-Late Pleistocene ones (Table 2) and, accordingly, the intensity ratio $I_{S m} / I_{I l t}$ in the early samples is about twice as high. On the other hand, kaolinite is present in almost all the Middle-Late Pleistocene samples (Table 2), mainly in the 2 to $20 \mu \mathrm{m}$ fraction, indicating that kaolinite crystals are frequently larger than $2 \mu \mathrm{m}$. Kaolinite is lacking in several Early Pleistocene samples and, in general, the chlorite+kaolinite content is lower (Table 1).

Scanning electron microscope observation of selected samples revealed the presence of fibrous phyllosilicates, mostly interpreted as palygorskite based on the X-ray diffraction data. These fibers are less than $3 \mu \mathrm{m}$ long and appear as cement coating other grains and developed on the edges of planar particles (Fig. 9A). In samples where XRD patterns showed evidence of sepiolite, delicate sinuous fibers have been observed filling pores and again at the boundaries of planar particles (Fig. 9B).

Transmission electron microscope analyses supported the presence of illite, chlorite, Al-smectite (mainly beidellite and minor montmorillonite), and palygorskite. No evidence of kaolinite has been found, confirming the XRD data that indicate kaolinite grain sizes larger than $2 \mu \mathrm{m}$. Illite and chlorite occur very frequently as rounded anhedral-subhedral plates, while Al-smectite shows anhedral morphologies with irregular outlines or ragged edges. Palygorskite appears as single and double fibers, sometimes very small in size $(0.1 \mu \mathrm{m})$.

The mineralogical differences between the Early and Middle-Late Pleistocene samples shown by XRD can be interpreted in different ways. The textural and morphological features mentioned above indicate that illite, chlorite, kaolinite, and Al-smectite are detrital constituents of the studied materials. Taking into account the distance between the location of the studied paleosinkholes, differences among sampled areas may be related with distinct relative influence of source areas during the Pleistocene. This hypothesis is supported by the fact that the only sample of Middle-Late Pleistocene age where kaolinite is clearly lacking (as in the Early Pleistocene samples), was collected at a geographic location close to the Early Pleistocene ones, so the absence of this mineral could be 


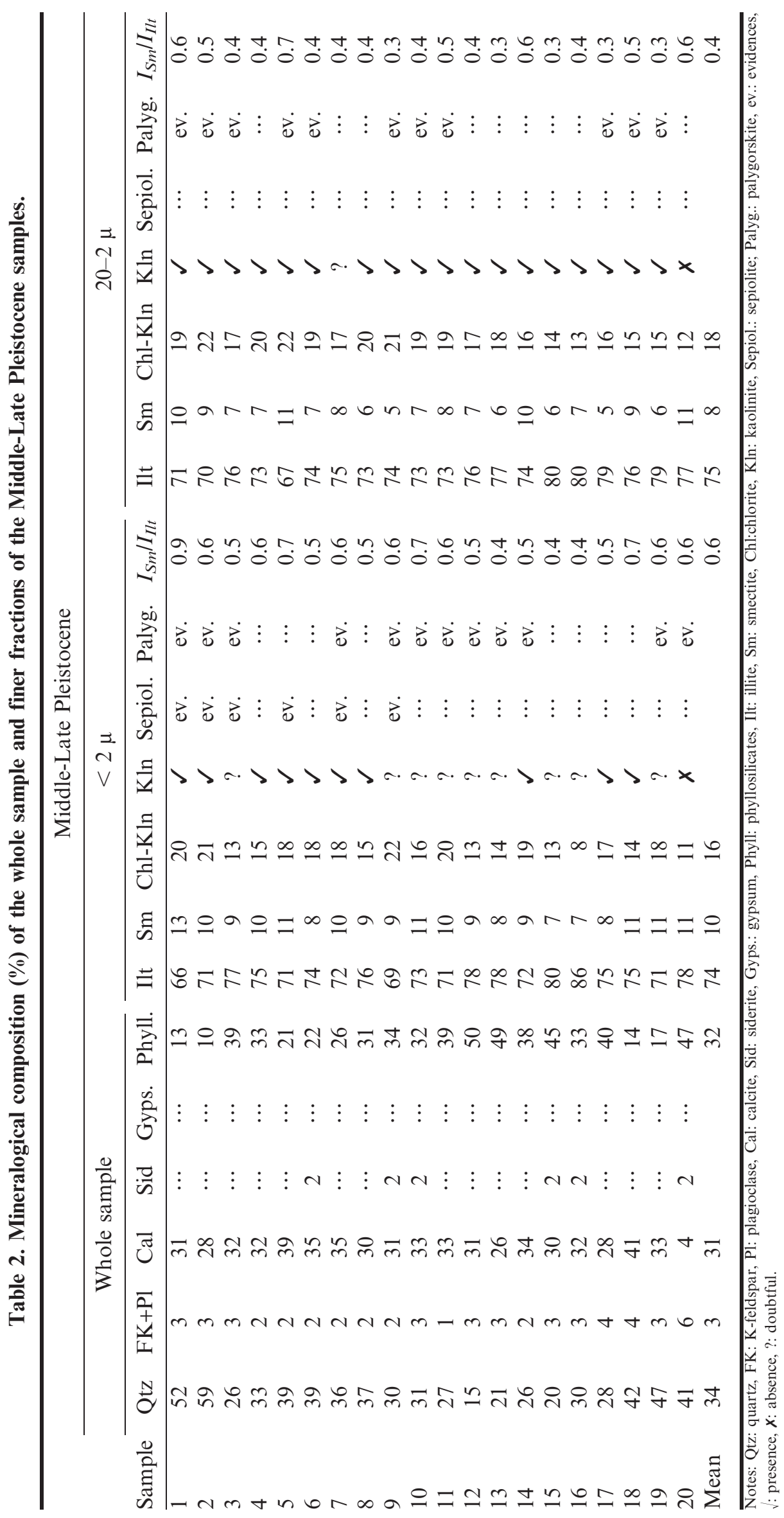



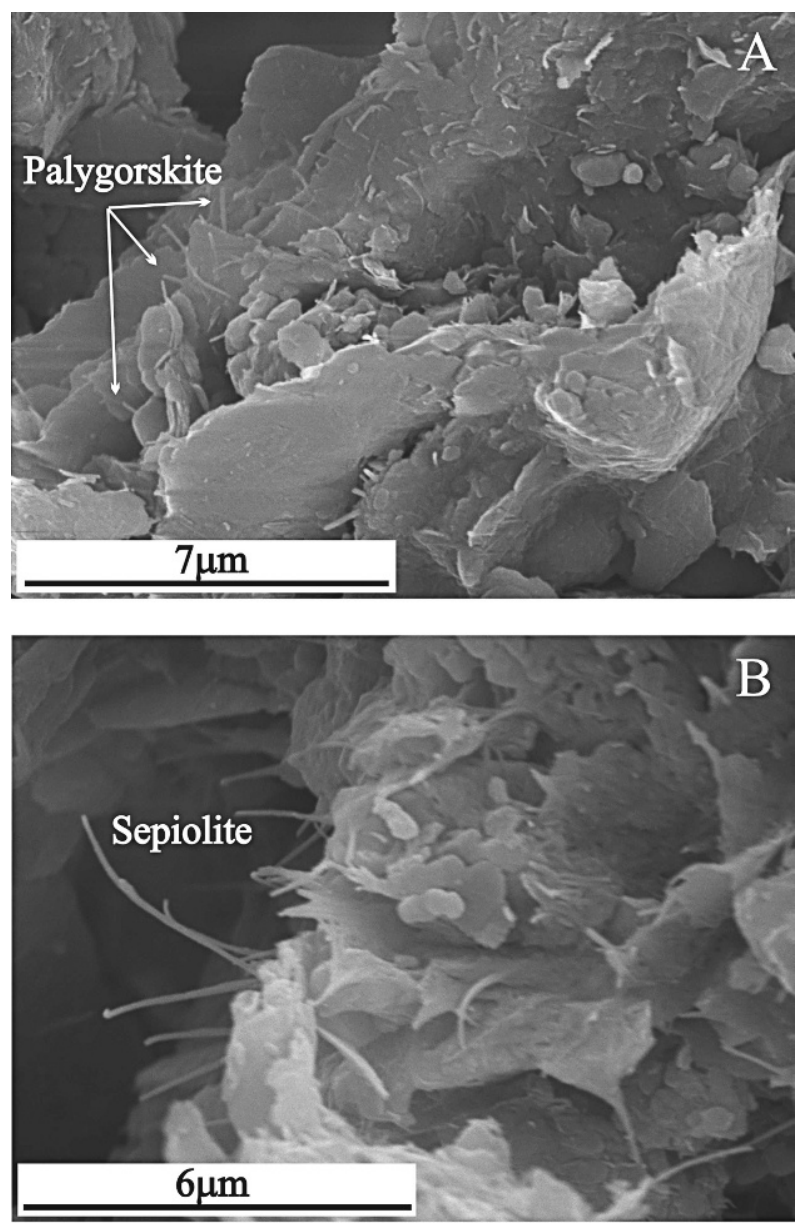

Figure 9. A, small fibers of authigenic palygorskite on the edge of planar phyllosilicates; in the lower right area, palygorskite fibers are covering other mineral grains. B, delicate fibrous sepiolite of authigenic origin.

related with its scarcity in the main source area that fed this site. However, if mineralogical differences were detected in the samples with different ages for the whole area, climate could be proposed as the main cause of such variations. In that case, the lower smectite contents and the widespread existence of kaolinite in the Late Pleistocene samples would be related to a change towards more humid conditions in the source areas, favoring the formation of kaolinite over smectite.

On the other hand, palygorskite and sepiolite show features indicative of authigenesis in both the early and later Pleistocene samples, in some cases, through the transformation of precursor clay minerals, probably smectite. The formation of these minerals would indicate arid to semi-arid environments during the Pleistocene, since the occurrence of palygorskite and sepiolite in continental lacustrine deposits, such as these, is indicative of those environments (Jones and Galán, 1988). This is in agreement with the possibility of repetitive glaciations during the Pleistocene.

\section{Structural Data}

Deformation of the Quaternary cover is an essential attribute of paleosinkholes, since normal and reverse faults, fractures, folds, and tilted beds are commonly observed either within or near them. Nevertheless, in the central Ebro Basin, not every deformation structure is genetically associated to karst subsidence and a detailed structural study is necessary to determine their origin from regional tectonics, karst activity, or occasional diapirism (Simón and Soriano, 1986; Arlegui and Simón, 2000). Karst subsidence usually produces local extensional structures (concentric normal faults and fractures), although contractional structures (reverse faults and reverse kink-bands) can appear as well if the sinking material shows high internal cohesion and low external cohesion with respect to the surrounding rock. Tectonic faults can be identified because they usually form conjugate systems striking parallel to the regional major horizontal stress trajectories, $\mathrm{N}-\mathrm{S}$ to NNW-SSE, in our case.

Interaction between tectonic and karst deformation is also common. Many paleosinkhole boundaries are controlled by faults that show regional trends and suggest strong control by the existing structural pattern (Soriano et al., 2010). Although the structure of Figure 8A has been characterized as a paleosinkhole, it is bounded by NNWSSE-striking faults that controlled the location of the sink's center by creating discontinuities that favored water infiltration and modified the mechanical properties of the Quaternary cover.

Besides discerning the possible relationships between karst and tectonics, the structural techniques provide information on the development stages of karst landforms. As an example, a paleokarst structure $3 \mathrm{~km}$ southwest of Fuentes de Ebro (Fig. 1), one of the many observed along the high-speed railway between Zaragoza and Barcelona, has been analyzed. The materials involved in the collapse are Neogene gypsum and marl, together with Quaternary gravel and sand (Fig. 10). The zone of maximum deformation involves partly folded and unstructured Quaternary gravel overlying fragments of gypsum and marls. Highangle reverse faults with opposite dips bound the collapsed zone and separate it from Neogene layers that are steeply tilted towards the center of the paleosinkhole. Far away, Neogene layers become horizontal. Analysis of the crosssection (Fig. 10B) points out that a part of the subsidence recorded by bed tilting occurred before deposition of the Quaternary deposits, since the latter lie unconformably on gypsum and marl beds dipping centripetally in the vicinity of the collapse. The restored cross-section (Fig. 10C) highlights this fact. When the beds are relocated to their original positions, a Neogene sequence would be placed in the vertical of the collapse zone; no such sequence is actually present beneath the Quaternary disconformity in the surrounding area. Fluvial activity continued after the collapse, as the thickening of gravel on top of the paleosinkhole indicates. 


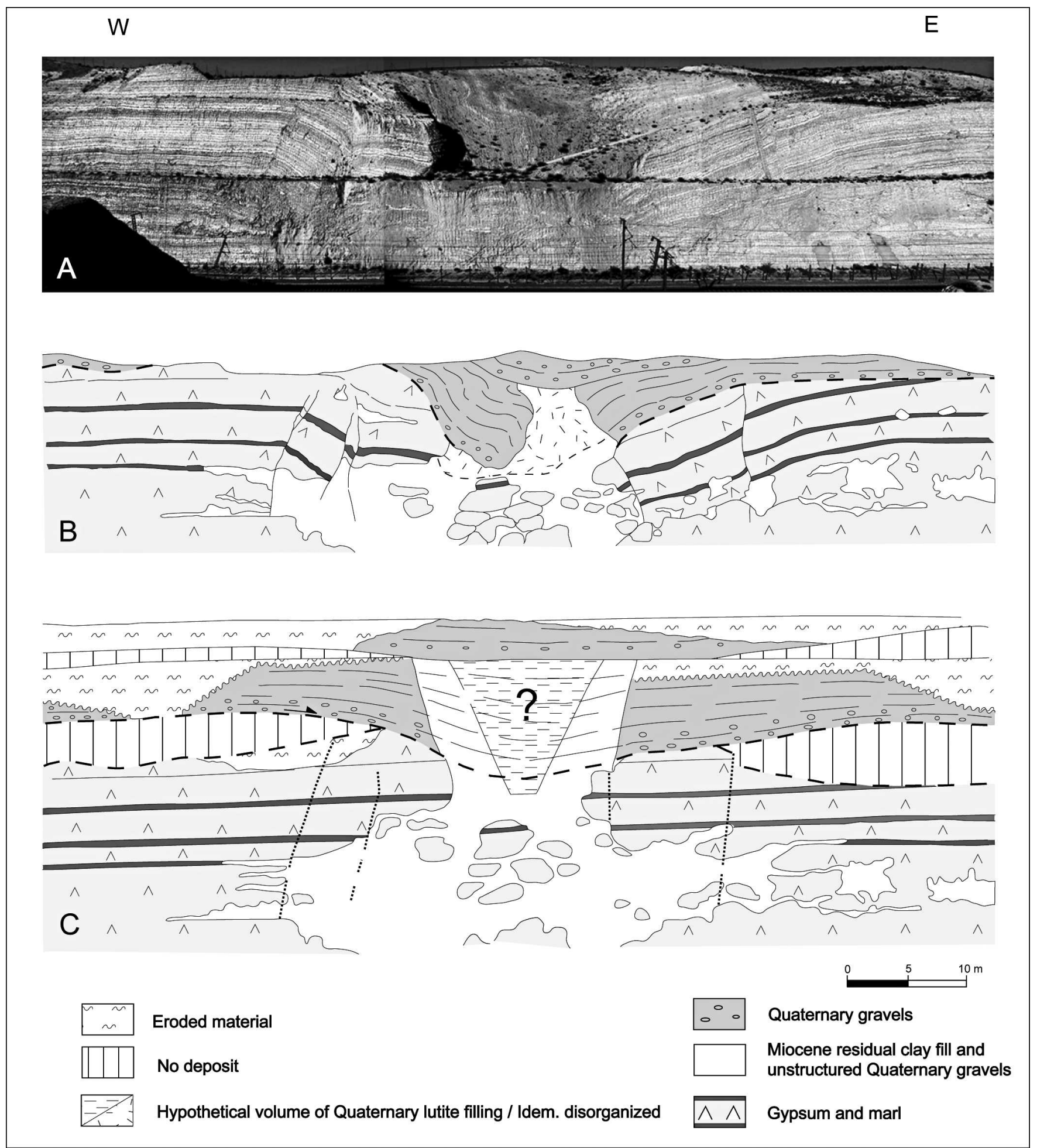

Figure 10. A and B, photograph and cross-section of a paleocollapse exposed on a slope of the high-speed railway, southwest of Fuentes de Ebro. In the lower right, several karst conduits can be seen. In the lower part of the collapsed area, blocks of Neogene materials appear, and in the upper part there are Quaternary gravels. The limiting Neogene beds are tilted and affected by reverse faults. C, restored cross-section that shows the occurrence of karstic subsidence previous to Quaternary sedimentation. 
From the analysis of sedimentary and structural data, several evolutionary episodes of collapse, subsidence, and suffosion in the development of the paleosinkholes were recognized (Luzón et al., 2008). The sedimentological and geomorphological context determined the height of the phreatic level and whether the sinkholes were flooded.

\section{Conclusions}

The abundance of sinkholes and paleosinkholes in the central Ebro Basin indicates that karstification has been active since the Early Pleistocene. The development of Pleistocene sinkholes was only conditioned by natural factors. Their study reveals data that can not be obtained from the present-day sinkholes.

The access to the inner structure of paleosinkholes shows that, very often, tectonic faults conditioned the location of sinking centers where preferential dissolution and later suffosion took place. In addition, evolutionary episodes in which collapses and progressive subsidence took place can be inferred using structural and sedimentological analysis. Dating of paleosinkholes infillings indicated that synsedimentary filling took thousands of years.

The study of sedimentary features of Early Pleistocene and Late Pleistocene terraces in the Ebro Basin indicates that they were deposited in a gravel braided fluvial system, with high water volume and sediment availability, a situation that clearly differs from the present-day hydrological conditions. The braided pattern could have been favored by melting of ice in surrounding glaciated source areas, with fluctuating water discharges reaching the central part of the Ebro Basin. Genesis of sinkholes at that time was probably related to higher water supply.

Some of the studied paleosinkholes were flooded and acted as small lakes where fine sediments accumulated, recording the regional paleoenvironmental conditions. Widespread evidence of palygorskite and sepiolite neoformation suggests arid to semi-arid climatic conditions in agreement with glacial episodes. The mineralogical differences between distinct sampled areas were probably related to different source areas.

In spite of the present-day semi-arid climate of the central Ebro Basin, active development of sinkholes continues due to the irrigation at almost twenty times the quantity of water provided by natural precipitation in the zone. Infiltration of this causes variations in the water table, a high hydraulic gradient, dissolution of evaporites, and mobilization of detrital materials.

\section{ACKNOWLEDGMENTS}

This work has been supported by projects PI 030/08 (Diputación General de Aragón), GA-LC-026/2009 (Diputación General de Aragón-Caixa), and UZ 2008-CIE-21 (Universidad de Zaragoza). Authors thank the reviewers for comments and suggestions that improved the initial version of the manuscript.

\section{REFERENCES}

Arlegui, L.E., and Simón, J.L., 2000, Fracturación y campos de esfuerzos en el Cuaternario del sector central de la Cuenca del Ebro (NE España): Cuaternario y Geomorfologia, v. 14, no. 1-2, p. 11-20.

Arlegui, L.E., and Soriano, M.A., 1998, Characterizing lineaments from satellite images and field studies in the central Ebro basin (Spain): International Journal of Remote Sensing, v. 19, p. 3169-3185. doi:10.1080/014311698214244.

Beach, T., Luzzadder-Beach, S., Dunning, N., and Cook, D., 2008, Human and natural impacts on fluvial and karst depressions of the Maya Lowlands: Geomorphology, v. 101, p. 308-331. doi:10.1016/ j.geomorph.2008.05.019.

Benito, G., and Casas, A.M., 1987, Small-scale deformations in Quaternary deposits in the northeastern Iberian Peninsula: Géologie Méditerranéenne, v. 15, p. 233-243.

Benito, G., Pérez-González, A., Gutiérrez, F., and Machado, M.J., 1998, River response to Quaternary subsidence due to evaporite solution (Gállego River, Ebro Basin, Spain): Geomorphology, v. 22, p. $243-$ 263. doi:10.1016/S0169-555X(97)00088-3.

Benito, G., Sancho, C., Peña, J.L., Machado, M.J., and Rhodes, E.J., 2010, Large-scale karst subsidence and accelerated fluvial aggradation during MIS6 in NE Spain: climatic and paleohydrological implications: Quaternary Science Reviews, v. 29, p. 2694-2704. doi:10.1016/ j.quascirev.2010.06.020.

Boothroyd, J.C., and Ashley, G.M., 1975, Processes, bar morphology, and sedimentary structures on braided outwash fans, northeastern gulf of Alaska, in Jopling, A.V., and McDonald, B.C., eds., Glaciofluvial and Glaciolacustrine Environments, Tulsa, Society of Economic Paleontologists and Mineralogists Special Publication 23, p. 193-222.

Chow, N., and Wendte, J., 2011, Palaeosols and palaeokarst beneath subaerial unconformities in an Upper Devonian isolated reef complex (Judy Creek), Swan Hills Formation, west-central Alberta, Canada: Sedimentology, v. 58, p. 960-993. doi:10.1111/j.1365-3091.2010.01191.x.

Closson, D., and Abou Karaki, N., 2009, Human-induced geological hazards along the Dead Sea coast: Environmental Geology, v. 58, p. 371-380. doi:10.1007/s00254-008-1400-3.

Colomer, M.V., Navarro, J.J., Hernández, A., and Ramírez, J.I., 2006, Mapa geológico de España: Pina de Ebro (412): Instituto Geológico y Minero de España, scale 1:50000, 1 sheet.

Confederación Hidrográfica del Ebro, 2010, Caracterización de la recarga en las masas de agua subterránea de la Cuenca del Ebro, Zaragoza, Ministerio de Medio Ambiente y Medio Rural y Marino, 35 p.

Cooper, A.H., and Calow, R.C., 1998, Avoiding Gypsum Geohazards: Guidance for Planning and Construction, Nottingham, British Geological Survey Technical Report WC/98/5, 57 p.

Currin, J.L., and Barfus, B.L., 1989, Sinkhole distribution and characteristics in Pasco County, Florida, in Beck, B.F., ed., Engineering and Environmental Impacts of Sinkholes and Karst: Proceedings of the Third Multidisciplinary Conference on Sinkholes and the Engineering and Environmental Impacts of Karst, St. Petersburg Beach, Florida, 2-4 October 1989, London, Balkema, p. 97-106.

Ford, D., and Williams, P., 2007, Karst Hydrogeology and Geomorphology: Chippenham, Wiley, $562 \mathrm{p}$.

Galve, J.P., Gutiérrez, F., Lucha, P., Bonachea, J., Remondo, J., Cendrero, A., Gutiérrez, M., Gimeno, M.J., Pardo, G., and Sánchez, J.A., 2009, Sinkholes in the salt-bearing evaporite karst of the Ebro River valley upstream of Zaragoza city (NE Spain): geomorphological mapping and analysis as a basis for risk management: Geomorphology, v. 108, p. 145-158. doi:10.1016/j.geomorph.2008.12.018.

García-Castellanos, D., Vergés, J., Gasper-Escribano, J., and Cloetingh, S., 2003, Interplay between tectonics, climate, and fluvial transport during the Cenozoic evolution of the Ebro Basin (NE Iberia): Journal of Geophysical Research, v. 108, no. B7, paper 2347, 18 p. doi:10.1029/ 2002JB002073.

García-Ruiz, J.M., and Martí Bono, C., 1994, Rasgos fundamentales del glaciarismo cuaternario en el Pirineo aragonés, in Martí Bono, C., and García Ruiz, J.M., eds., El glaciarismo surpirenaico: Nuevas aportaciones: Logroño, Spain, Geoforma Ediciones, p. 17-32. 
Gutiérrez, F., Guerrero, J., and Lucha, P., 2008, A genetic classification of sinkholes illustrated from evaporite paleokarst exposures in Spain: Environmental Geology, v. 53, p. 993-1006. doi:10.1007/s00254-007$0727-5$.

Gutiérrez-Santolalla, F., Gutiérrez-Elorza, M., Marín, C., Desir, G., and Maldonado, C., 2005a, Spatial distribution, morphometry and activity of la Puebla de Alfindén sinkhole field in the Ebro river valley (NE Spain): applied aspects for hazard zonation: Environmental Geology, v. 48, p. 360-369. doi:10.1007/s00254-005-1280-8.

Gutiérrez-Santolalla, F., Gutiérrez-Elorza, M., Marín, C., Maldonado, C., and Younger, P.L., 2005b, Subsidence hazard avoidance based on geomorphological mapping in the Ebro river valley mantled evaporite karst terrain (NE Spain): Environmental Geology, v. 48, p. 370-383. doi:10.1007/s00254-005-1281-7

Jia, Y., and Yuan, D., 2004, The influence of land use change on karst water quality of Shuicheng Basin in Guizhou Province: Journal of Geographical Sciences, v. 14, p. 143-150. doi:10.1007/BF02837529.

Jones, B.F., and Galán Huertos, E., 1988, Sepiolite and palygorskite, in Bailey, S.W., ed., Hydrous Phyllosilicates (Exclusive of Micas), Washington, Mineralogical Society of America Reviews in Mineralogy, v. 19 , p. $631-674$.

Lamelas, M.T., Marinoni, O., Hopper, A., and de la Riva, J., 2008, Doline probability map using logistic regression and GIS technology in the central Ebro Basin (Spain): Environmental Geology, v. 54, p. 963-977. doi:10.1007/s00254-007-0895-3.

Luzón, A., Pérez, A., Pocoví, A., Soriano, M.A., Gil, H., RodríguezLópez, J.P., and Simón, J.L., 2011, Sedimentary record related to the evolution of Quaternary dolines in the central Ebro Basin in Arenas, C., Pomar, L., and Colombo, F., eds., Pre-Meeting Field Trips Guidebook, 28th IAS Meeting of Sedimentology, Zaragoza (Spain), Geo-Guias 8, p. 199-226.

Luzón, A., Pérez, A., Soriano, M.A., and Pocoví, A., 2008, Sedimentary record of Pleistocene paleodoline evolution in the Ebro basin (NE Spain): Sedimentary Geology, v. 205, p. 1-13. doi:10.1016/j.sedgeo. 2008.01.004.

Maizels, J.K., 1997, Jökulhlaup deposits in proglacial areas: Quaternary Science Reviews, v. 16, p. 793-819. doi:10.1016/S0277-3791(97)00023-1.

Mancini, F., Stecchi, F., Zanni, M., and Gabbianelli, G., 2009, Monitoring ground subsidence induced by salt mining in the city of Tuzla (Bosnia and Herzegovina): Environmental Geology, v. 58, p. 381-389. doi:10.1007/s00254-008-1597-1.

Marqués, L.A., Santos, J.A., Esnaola, J.M., and Gil Marín, C., 1998, Mapa geológico de España: Fuentes de Ebro (384): Instituto Geológico y Minero de España, scale 1:50000, 2nd series, 1 sheet.

Miall, A.D., 1978, Lithofacies types and vertical profile models in braided river deposits: a summary, in Miall, A.D., ed., Fluvial Sedimentology, Canadian Society of Petroleum Geologists, Memoir 5, p. 597-604

Muñoz, A., Arenas, C., González, A., Luzón, A., Pardo, G., Pérez, A., and Villena, J., 2002, Ebro Basin (northeastern Spain), in Gibbons, W., and Moreno, T., eds., The Geology of Spain, Bath, Geological. Society of London, p. 301-309.

Pardo, G., Arenas, C., González, A., Luzón, A., Muñoz, A., Pérez, A., Pérez Rivarés, F.J., Vázquez-Urbez, M., and Villena, J., 2004, La Cuenca del Ebro, in Vera, J.A., ed., Geología de España, Madrid, Sociedad Geológico de España-Instituo Geológico y Minero de España, p. 533-539.
Pueyo-Anchuela, Ó., Casas-Sainz, A.M., Soriano, M.A., Pocoví Juan, A., Ipas-Lloréns, J.F., and Ansón-López, D., 2010, Integrated geophysical and building damages study of karst effects in the urban area of Alcalá de Ebro, Spain: Zeitschrift für Geomorphologie, v. 54, supplement no. 2, p. 221-236. doi:10.1127/0372-8854/2010/0054S20012 .

Rust, B.R., 1978, A classification of alluvial channel systems, in Miall, A.D., ed., Fluvial Sedimentology, Canadian Society of Petroleum Geologists, Memoir 5, p. 187-198.

Shunk, A.J., Driese, S.G., and Michael Clark, G., 2006, Latest Miocene to earliest Pliocene sedimentation and climate record derived from paleosinkhole fill deposits, Gray Fossil Site, northeastern Tennessee, U.S.A.: Palaeogeography, Palaeoclimatology, Palaeoecology, v. 231, p. 265-278. doi:10.1016/j.palaeo.2005.08.001.

Simón, J.L., and Soriano, M.A., 1986, Diapiric deformations in the Quaternary deposits of the central Ebro Basin, Spain: Geological Magazine, v. 123, p. 45-57.

Simón-Gómez, J.L., Soriano Jiménez, M.A., Arlegui Crespo, L., and Caballero Burbano, J., 1998, Estudio de riesgos de hundimientos kársticos en el corredor de la carretera de Logroño, Departamento de Geología, Universidad de Zaragoza, Memoria: http://www.zaragoza.es/ contenidos/urbanismo/pgouz/memoria/anejos/anejo03/anejo032.pdf, [accessed September 1, 2011].

Simón, J.L., Soriano, M.A., Arlegui, L.E., Gracia, J., Liesa, C.L., and Pocoví, A., 2008, Space-time distribution of ancient and active alluvial karst subsidence: examples from the central Ebro Basin, Spain: Environmental Geology, v. 53, p. 1057-1065. doi:10.1007/s00254-0070732-8.

Soriano Jiménez, M.A., 1990, Geomorfología del sector centromeridional de la depresión del Ebro, Zaragoza, Institución Fernando El Católico, $269 \mathrm{p}$.

Soriano, M.A., 1992, Characteristics of the alluvial dolines developed because of gypsum dissolution in the central Ebro Basin (Spain), in Nicod, J., Pfeffer, K.-H., and Sweeting, M., eds., Geomorphology and Geoecology, Karst, Proceedings of the Second International Conference on Geomorphology and Geoecology, Frankfurt/Main 1989, Volume VII: Zeitscrift fur Geomorphologie Supplements, no. 85, p. $59-72$.

Soriano, M.A., Luzón, A., Pérez, A., Pocoví, A., Simón, J.L., and Gil, H., 2010, Past and present doline development in the Central Ebro Basin (NE Spain), in Proceedings, $2^{\circ}$ Workshop Internazionale Sinkholes, Roma, Istituto Superiore per la Protezione e la Ricerca Ambientale, p. $359-370$.

Soriano, M.A., and Simón, J.L., 2002, Subsidence rates and urban damages in alluvial dolines of the Central Ebro basin (NE Spain): Environmental Geology, v. 42, p. 476-484. doi:10.1007/s00254-0010508-5.

van Beynen, P., and Townsend, K., 2005, A disturbance index for karst environments: Environmental Management, v. 36, no. 1, p. 101-116. doi:10.1007/s00267-004-0265-9.

White, W.B., 1988, Geomorphology and Hydrology of Karst Terrains: New York, Oxford University Press, 464 p.

Zielinski, T., and Van Loon, A.J., 2003, Pleistocene sandur deposits represent braidplains, not alluvial fans: Boreas, v. 32, p. 590-611. doi:10.1111/j.1502-3885.2003.tb01238.x. 